\title{
Stavovi pripadnika Romske populacije na području Bjelovarsko-bilogorske županije o obiteljskom nasilju
}

1 Aleksandar Racz

2 Veljko Kajtazi

1 Zdravstveno veleučilište

2 Savez Roma u Republici Hrvatskoj „Kali Sara“

\section{Sažetak}

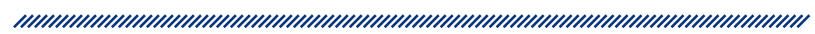

Opći cilj postavljen hrvatskom Nacionalnom strategijom za uključivanje Roma jest poboljšati položaj romske nacionalne manjine u Republici Hrvatskoj smanjivanjem višedimenzionalnog jaza između romskog i ostalog stanovništva te na usklađen, otvoren i transparentan način postići potpuno uključivanje Roma u sve segmente društva i zajednice. Glavni cilj istraživanja bio je istražiti stavove pripadnika Romske populacije s područja Bjelovarsko-bilogorske županije o nasilju u obitelji te istražiti vrstu i razmjere njihove izloženosti pojedinim oblicima nasilja. Pomoćni cilj bio je istražiti uvjerenja i stavove ispitanika o prošnji među djecom te uvjerenja i stavove ispitanika o povjerenju u institucije kao mjesta prijave nasilja i pružanja zaštite žrtvi u slučajevima izloženosti obiteljskom nasilju. Istraživanje je provedeno metodom anketiranja na prigodnom uzorku od 70 ispitanika koji su bili polaznici edukacijskih radionica na temu usvajanja socijalnih vještina usmjerenih na smanjenje neprihvatljivog ponašanja kod djece i mladih u organizaciji Saveza Roma „Kali Sara” na području Grubišnog Polja i Bjelovara u siječnju 2019. godine. Podaci su obrađeni standardnim programskim paketom SPSS.

Ključne riječi: obiteljsko nasilje, Romi, integracija, Savez Roma u Republici Hrvatskoj „Kali Sara”

Datum primitka: 15.01.2019.

Datum prihvaćanja: 10.02.2019.

DOI: $10.24141 / 1 / 5 / 1 / 5$

Adresa za dopisivanje: Aleksandar Racz Zdravstveno veleučilište

Tel.: 385912334565

E-pošta: aracz@zvu.hr

Rezultati su potvrdili sve tri hipoteze istraživanja, i to: da nema razlike u incidenciji izloženosti nasilju u obitelji izmedu pripadnika romske nacionalne manjine u odnosu na sekundarne podatke o izloženosti nasilju u iznimno rijeko prijavljuju dožiljeno nasije u obitelj, iznimno rijetko prijavljuju dož́vijeno nasilje u obitelji, o odnosima nasiln - zrtva i jasno izgrađene stavove o odnosima nasilnik - žrtva i dijeli predrasude o krivnji žrtve za doživljeno nasilje. 


\section{Uvod}

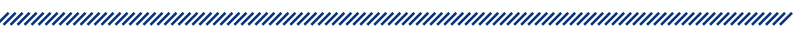

Unazad desetak tisuća godina, od prvih postanaka civilizacija, obitelj ima neprijepornu važnost kao temeljna društvena skupina uz koju se vežu najvažnije etičke i kulturne vrijednosti. Njezin značaj potvrđen je i u najvažnijim dokumentima brojnih međunarodnih tijela i organizacija. Primjerice, u zaključku 40. sjednice Odbora za prava djece UN-a održane 2005. godine ističe se da je prvenstveno obitelj prirodno okruženje za opstanak, zaštitu i razvoj svih svojih članova. Također se i u Preambuli Konvencije o pravima djeteta naglašava da je obitelj najbolje okruženje ne samo za emocionalnu, materijalnu i financijsku potporu nego i za razvoj i rast kako djece tako baš svih svojih članova.

Takvi trendovi pokazuju da je obitelj ušla u krizu, pri čemu je „kriza obitelji” zapravo postala „krizom svijeta", upravo zato što su poremećene vrednote koje čini obitelj pravom, temeljnom, istinitom stanicom ljudskoga društva. Kako ističe Valković (1996.) obitelj je danas „veliki siromah". ${ }^{1}$ Takva obitelj svim svojim članovima više ne pruža blagotvorno okruženje prihvaćanja i uvažavanja. Pritom obitelj koja je zapala u krizu sve teže može biti izvor pravoga ljudskog zadovoljstva, stabilnosti, sigurnosti i sreće. Opterećenje radnim vremenom u uvjetima gruboga neoliberalnog kapitalističkog sustava dovodi do vulgarizacije i reduciranja sadržaja obiteljskog života. Pritom stresne i neurotične prilike dovode suvremenu obitelj do izazova u kojima nisu strane ni konfliktne situacije koje kulminiraju u vidu otvorenih sukoba i različitih vidova nasilja u obitelji. Štoviše, obiteljsko nasilje, a posebice nasilje nad ženom u obitelji, danas nije rijetkost. Posljednja četiri desetljeća ruše se stereotipi o idealnoj obitelji i uvjerenju da se dostojanstvena starost može doživjeti u krugu najbližih. ${ }^{2}$ Brojna klinička i empirijska iskustva pokazala su da je obitelj često i nasilno okruženje u kojem se najbrutalnije krše temeljna ljudska prava njezinih članova, što u najvećem dijelu ostaju neprepoznato, čak i u slučajevima teških i fatalnih ishoda. Nažalost, Ajduković (2003.) s pravom konstatira da je obitelj od oaze ljubavi i sigurnosti za mnoge postala krugom nasilja, izgovor za brutalna iživljavanja nad slabijim, podčinjenim članom, gotovo u pravilu djetetom, a često i ženom. ${ }^{2}$

S klasičnog antropološkog gledišta obitelj je sve donedavno predstavljana kao skupina sastavljena od žene, njezine djece i barem jednog muškarca vezanih brakom ili krvnim srodstvom. U skladu s time, u posljednjih 60 godina obitelj se definira i kao društvena skupina koju karakterizira zajedničko prebivanje, ekonomska suradnja i reprodukcija, a koja nužno obuhvaća više odraslih osoba oba spola od kojih barem dvije održavaju društveno prihvaćenu seksualnu kohabitaciju i imaju jedno ili više vlastite ili usvojene djece. Neki je autori shvaćaju kao multifunkcionalnu instituciju koja je nezaobilazna za društvo, dok drugi autori također naglašavaju da je obitelj prirodno mjesto za život njezinih članova, mjesto materijalne sigurnosti i emocionalne topline. S aspekta rimokatoličke teologije, čija je doktrina ukorijenjena u našem društvu, obitelj je prauzor zajedništva, odnosno zajednica osoba kojima je temelj vlastitog načina postojanja i zajedničkog življenja upravo zajedništvo. Posebno se ističe da je osobito važna uloga obitelji na razini početnih identifikacija i emocionalnih iskustava. $\mathrm{Na}$ taj je način obitelj, kao početna matrica čovjekove ličnosti, od nepobitne važnosti za svako dijete i ima svoje posljedice na kasniji razvoj ličnosti, pri čemu se međuodnosu roditelja pripisuje prvorazrednu važnost u kasnijem manifestiranju nasilnih oblika ponašanja nad partnericom.

Nasilje nad ženom u obitelji dio je vrlo raširenog nasilja koje u raznim oblicima zahvaća sve strukture većine društava današnjeg svijeta. Usprkos univerzalnosti pojave, nedostaje i univerzalno prihvaćena definicija nasilja. ${ }^{3}$ Razmjeri raširenosti nasilja nad ženom u obitelji, a posebice nasilja počinjenog nad ženom od bračnih ili intimnih partnera, zabrinjavajući su i, javnozdravstvenim rječnikom, poprimaju razmjere pandemije. Nasilje je, nažalost, samo jedan od oblika podčinjenosti i rodne neravnopravnosti koje žena trpi u današnjem svijetu. Vijeće Europe (2002.) objavilo je podatak da je 20 do $50 \%$ žena u Europi tijekom života bilo žrtvama obiteljskog nasilja. ${ }^{4}$ Podaci o incidenciji nasilja nad ženama u nekim europskim zemljama pokazuju da su žene tijekom života u velikom broju izložene fizičkom nasilju (Češka $35 \%$, Danska $30 \%$, Poljska $15 \%$ ), kao i spolnom nasilju (Češka $11 \%$, Danska 8 \%, Poljska $5 \%$ ). ${ }^{5}$ Godeč (2000.) je u istraživanju provedenom na 1000 ispitanica dobila rezultate koji pokazuju da 45,5 \% ispitanika osobno poznaje ženu koja je pretrpjela nasilje, dok 15,1\% poznaje osobu koja je bila silovana. ${ }^{6}$ Podaci o nasilju nad djecom govore da su tijekom djetinjstva u 15,9\% slučajeva bila izložena tjelesnom zlostavljanju, 16,5 \% emocionalnom, 14,8\% ispitanika svjedočilo je nasilju u obitelji, a $14 \%$ navodi da je bilo spolno zlostavljano. ${ }^{7}$

Republika Hrvatska u skladu s Okvirom Europske unije za nacionalne strategije integracije Roma do 2020. do- 
nijela je Nacionalnu strategiju uključivanja Roma za razdoblje od 2013. do 2020. godine krajem 2012. godine, dok je Akcijski plan za provedbu Nacionalne strategije za uključivanje Roma za razdoblje od 2013. do 2015. godine usvojen početkom 2013. godine. ${ }^{8}$

Opći cilj postavljen hrvatskom Nacionalnom strategijom za uključivanje Roma jest poboljšati položaj romske nacionalne manjine u Republici Hrvatskoj smanjivanjem višedimenzionalnog socioekonomskog jaza između romskog i ostalog stanovništva te na usklađen, otvoren i transparentan način postići potpuno uključivanje Roma u sve segmente društva i zajednice.

Kako bi se taj cilj ostvario, Nacionalna strategija za uključivanje Roma za razdoblje od 2013. do 2015. godine uključuje sljedeća četiri posebna cilja, od kojih je vrlo važno sustavno raditi na poboljšanju društvenog položaja Roma stvaranjem pretpostavki za ostvarivanje temeljnih ljudskih i manjinskih prava, uklanjanjem svih oblika diskriminacije te poticanjem aktivnog sudjelovanja u društvu i procesima odlučivanja. Romi su u Republici Hrvatskoj, kao i u mnogim zemljama u kojima žive, zbog slabe obrazovanosti, neuključenosti u formalne oblike rada, specifičnog načina življenja i drugih karakteristika u većoj ili manjoj mjeri marginalizirani: ekonomski, prostorno, kulturološki i politički. Ocijenivši položaj romske zajednice težim od položaja drugih manjinskih zajednica u Europi, Vijeće Europe i Europska unija od 1993. godine, a posebice posljednjih desetak godina, posvećuju osobitu pozornost problematici Roma kao najbrojnijoj nacionalnoj manjini u Europi te potiču države članice i druge države u regiji na sustavno rješavanje problema romske zajednice, kako bi se zatečeni jaz što brže prebrodio, a uvjeti življenja Roma poboljšali. Pri tomu svojim rezolucijama i preporukama apeliraju na multidisciplinarni i sustavni pristup u rješavanju problema na svim područjima, a posebice se zalažu za ostvarivanje prava djece i žena, omogućavanje stjecanja obrazovanja, osiguravanje zdravstvene i socijalne zaštite, primjerenog stanovanja te iskorjenjivanje diskriminacije i segregacije po bilo kojoj osnovi, uključujući rasnu, nacionalnu, vjersku i spolnu. ${ }^{8}$ Kao krajnji cilj često se pogrešno ističe postizanje suživota. Međutim Romi ne žele suživot, nego žele živjeti, a to je moguće ostvariti tek značajnim promjenama u odnosu većinskog naroda prema manjinskom. Kako bi navedeno se moglo uspješno realizirati, kao i ostvariti pojedine segmente unutar ciljeva zacrtanih Akcijskim planovima, potrebno je prethodno provesti terenska istraživanja kako bi se razumjele polazne osnove i dobili inicijalni podaci. Jedini sustavni dokument koji donosi rezultate dosad provedenog istraživanja kvalitete života Roma u $\mathrm{RH}$ jest dokument Uključivanje Roma u hrvatsko društvo: istraživanje baznih podataka, koji u manjem dijelu obrađuje nekoliko pitanja na temu obiteljskog nasilja i nasilja nad ženama i djecom, što je upotrijebljeno u usporedbi rezultata dobivenih ovim istraživanjem. ${ }^{9}$

Radionice koje provodi Savez Roma u Republici Hrvatskoj „Kali Sara” usmjerene na usvajanje socijalnih vještina i time usmjerene na smanjenje neprihvatljivog ponašanja ili izloženosti neprihvatljivom ponašanju, posebice kod djece i mladih, kvalitetan su doprinos osnaživanju romske populacije. Istraživanja koja se provode u sklopu radionica pružaju inicijalne podatke za razumijevanje dubine pojedinih problema i pružaju putokaz u kojem smjeru treba fokusirati djelovanje svih dionika u procesu potpore romskoj zajednici. Istraživanja o incidenciji obiteljskog nasilja kod Roma u pravilu nisu provedena na razini $\mathrm{RH}$ i ne postoje sustavno prikupljeni podaci. Ovo je istraživanje predstavlja simboličan doprinos u osvjetljavanju tog područja.

\section{Cilj i svrha rada}

Glavni cilj istraživanja bio je istražiti stavove pripadnika Romske populacije s područja Bjelovarsko-bilogorske županije o nasilju u obitelji te istražiti vrstu i razmjere njihove izloženosti pojedinim oblicima nasilja. Pomoćni cilj bio je istražiti uvjerenja i stavove ispitanika o prošnji među djecom te uvjerenja i stavove ispitanika o povjerenju u institucije kao mjesta prijave nasilja i pružanja zaštite žrtvi u slučajevima izloženosti obiteljskom nasilju.

\section{Mjesto i vrijeme provođenja istraživanja}

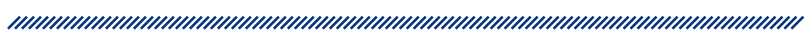

Istraživanje je provedeno na dvije lokacije - na lokaciji grada Bjelovara i Grubišnog Polja. Bjelovar je grad u Hrvatskoj, središte Bjelovarsko-bilogorske županije i Bjelovarsko-križevačke biskupije. Jedan je od mlađih 
gradova u Hrvatskoj, nastao 1756. godine. Grad Bjelovar smješten je na visoravni u južnom dijelu Bilogore (sjeverozapadna Hrvatska) na 135 metara nadmorske visine. Bjelovar je sjedište Bjelovarsko-bilogorske županije, ali i prirodno, kulturno i političko središte ovog kraja. Bjelovar se smjestio u sjeveroistočnom rubnom dijelu plodne lonjsko-ilovske zavale, podno jugozapadnih obronaka Bilogore. Položen je između rječica Bjelovacke i Plavničke. Područje lonjsko-ilovske zavale nalazi se između 120 i 160 m nadmorske visine. Grubišno Polje smješteno je na jugozapadnim obroncima Bilogore. Područje grada prostire se na površini od $269 \mathrm{~km}^{2}$ te je površinom najveća samoupravna jedinica u Bjelovarsko-bilogorskoj županiji i čini 10,18 \% ukupne površine županije. Južnu granicu područja grada čini gornji tok rijeke llove, dok sjeveroistočnu čine bilogorski prijevoji.

U Bjelovarsko-bilogorskoj županiji Romi su po brojnosti četvrta zastupljena manjina na području županije, iza Čeha, Srba i Albanaca. Prema podacima, njihov je broj 1991. godine bio 144, stagnirao je tijekom sljedećih deset godina i u 2001. iznosio 140 te snažno porastao u zadnjem desetljeću te ih je prema popisu stanovništva iz 2011. godine bilo ukupno 391. Na području grada Bjelovara, prema popisu iz 2011., registrirano je ukupno 293 Roma, koji čine 0,73 \% ukupnog stanovništva. Romi kao manjinska zajednica nisu organizirani u vijeće, već ih predstavlja izabrani predstavnik. Problematika romske zajednice manifestira se u gotovo svim segmentima života, i to: zdravstvu, socijalnoj zaštiti, obrazovanju mladih i odraslih, kulturi, stanovanju i zapošljavanju. Određene stoljetne navike veći dio Roma ne napušta. Akcijski plan za Rome od 2005. do 2015. godine završio je $2 / 3$ postojanja, no nije bilo bitnih pomaka u rješavanju određenih problema (stanovanje i obrazovanje) te legalizacije ili su zanemarivi. Najveći su problem materijalna sredstva, a svi do sada donijeti i usvojeni planovi, od nacionalnog, županijskog do gradskog, ostaju samo planovi jer nisu praćeni potrebnim sredstvima. $\mathrm{Na}$ području županije provodi se program edukacije romske djece, rada na računalu te pripreme za školsko obrazovanje. Vrijeme provođenja istraživanja: siječanj 2019. na području grada Bjelovara i Grubišnog Polja na slučajnom uzorku.

\section{Metoda provođenja}

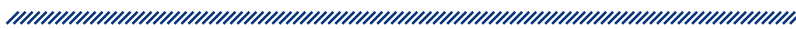

$\mathrm{U}$ istraživanju je primijenjen standardizirani upitnik s 23 pitanja u kojima su ispitanici odgovore iznosili u tri dijela. Prvi dio bio je povezan sa socijalno-demografskim obilježjima ispitanika (dob, spol, obrazovni status), drugi dio odnosio se na uvjerenja i stavove ispitanika prema nasilju u obitelji, u kojem su na određene mitove i tvrdnje o obiteljskom nasilju ispitanici iznosili vlastiti stupanj slaganja na Likertovoj skali od pet stupnjeva, a treći se dio odnosio na istraživanje osobne izloženosti raznim oblicima nasilja u obitelji i istraživanju povjerenja u sustav. Upitnici su distribuirani tijekom jednodnevnih radionica u organizaciji Saveza Roma u Republici Hrvatskoj „Kali Sara” u Bjelovaru i Grubišnom Polju. Svi ispitanici dobili su jasnu uputu o načinu ispunjavanja upitnika, prethodno su dali informirani pristanak za sudjelovanje u ispitivanju ili su pristanak dale osobe u njihovoj pratnji te je anonimnosti bila u potpunosti zajamčena. Od osoba se nije tražilo da iskažu svoju nacionalnost, poštujući pravo privatnosti prema odredbama GDPR-a, no budući da je bila riječ o radionicama u organizaciji Saveza Roma kao krovnog saveza lokalnih udruga Roma, pretpostavka je bila da su svi ispitanici romske nacionalne manjine ili osobe $u$ vrlo bliskoj vezi s pripadnicima romske nacionalne manjine. Podaci su obrađeni primjenom standardnog statističkog paketa SPSS, a za ovu svrhu prikazani su rezultati deskriptivne obrade.

\section{Hipoteze istraživanja}

U skladu s postavljenim ciljevima postavljene su tri hipoteze istraživanja.

H1 - Nema razlike u incidenciji izloženosti nasilju u obitelji između pripadnika romske nacionalne manjine $u$ odnosu na sekundarne podatke o izloženosti nasilju u obitelji kod neromske populacije u RH.

H2 - Žrtve nasilja iznimno rijetko prijavljuju doživljeno nasilje u obitelji i pokazuju nepovjerenje prema institucijama u sustavu.

H3 - Romska populacija nema jasno izgrađene stavove o odnosima nasilnik - žrtva i dijeli predrasude o krivnji žrtve za doživljeno nasilje. 


\section{Rezultati i diskusija}

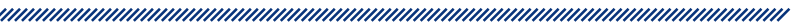

Istraživanje je provedeno na uzorku od 70 ispitanika na populaciji polaznika edukacijskih radionica na temu Usvajanje socijalnih vještina usmjerenih na smanjenje neprihvatljivog ponašanja kod djece i mladih.

\subsection{Opis uzorka}

U uzorku je bilo zastupljeno $32 \%$ muških i 68 \% ženskih ispitanika. S obzirom na to da su radionice bile namijenjene mladima, $51 \%$ ispitanika bili su učenici u dobi od 14 do 16 godina, a $49 \%$ učenici i osobe starije od 16 godina.

\subsection{Odnos prema nasilju u obitelji}

Ispitanici su na pitanje „Jeste li u svojoj okolini kada imali saznanja o prisutnosti nasilja u obitelji?" odgovorili da ih je $57 \%$ imalo saznanja o prisutnosti nasilja u obitelji, u odnosu na $43 \%$ koji takva saznanja nemaju.

Na pitanje „Kada biste imali saznanje o nasilju u obitelji, biste li to prijavili?" ispitanici su u vrlo visokom postotku, njih $84 \%$, rekli da bi prijavili nasilje. Zabrinjava, međutim, još uvijek prevelik postotak onih, njih $16 \%$, koji ne bi prijavili nasilje, vjerojatno iz neznanja ili straha.

Kako bi otklonili nedoumice oko uzroka neprijavljivanja, ispitanicima je postavljeno pitanje „Znate li kome morate prijaviti nasilje u obitelji?" i gotovo je isti postotak ispitanika ( $86 \%$ ) izjavio da zna kome mora prijaviti nasilje, što upućuje da oni koji ne bi prijavili nasilje većinom nemaju jasnu informaciju kome se prijavljuje nasilje.

Prilikom analize kojim bi institucijama prvo prijavili nasilje u obitelji uočljivo je da ispitanici policiju prepoznaju kao instituciju prvog izbora, jer je policiju istaknulo njih $62 \%$. Centar za socijalni rad, odnosno institucije socijalne skrbi istaknulo je $26 \%$ ispitanika, a preostalih $10 \%$ pomoć bi potražilo u školi. Zanimljivo je da nitko ne bi pomoć potražio u krugu savjetovališta ili udruga, a tek $1 \%$ ispitanika pomoć bi tražio od rodbine ili prijatelja. Zabrinjava nisko povjerenje u obrazovne institucije, posebice školske psihologe ili učitelje, što može voditi prema pretpostavci o slabijoj integraciji i inkluziji romske djece u obrazovni sustav, što i jest problem $\mathrm{s}$ kojim se Romi susreću u većini obrazovnih institucija u zemlji. Također udruge, posebno romske udruge kojih na području Bjelovarsko-bilogorske županije ima desetak, očigledno nisu prepoznate kao mjesto na kojima se može zatražiti pomoć, vjerojatno zbog straha od mogućeg prenošenja informacija u krugu romske zajednice i mogućeg izlaska s tim informacijama i prema obitelji ili prema zlostavljaču.

Na pitanje da sami odaberu koji oblik nasilja smatraju najtežim oblikom nasilja u obitelji ispitanici su mogli odabrati između fizičkog nasilja, psihičkog nasilja, ekonomskog nasilja, seksualnog nasilja ili podjednakog vrednovanja svih nabrojanih oblika nasilja po težini u najvećem postotku odabrali seksualno nasilje kao najteže (39\%), u odnosu na fizičko nasilje (16\%), psihičko nasilje (4 \%) i ekonomsko nasilje (1\%). Iznenađuje, međutim, da je također $39 \%$ sve oblike nasilja označio podjednako teškima.

\subsection{Osobna izloženost ispitanika pojedinim vrstama nasilja}

U grupi pitanja o prosjačenju kao obliku nasilja nad djecom čak $93 \%$ ispitanika ispravno prepoznaje da je prosjačenje djece također oblik zlostavljanja. Također, njih $96 \%$ nikad nije bilo tjerano na prosjačenje te gotovo svi $(98 \%)$ svoju djecu ne bi nikad tjerali na prosjačenje. Međutim, ovdje nam se otvara priznanje $4 \%$ ispitanika koji su izrijekom priznali da su bili tjerani na prosjačenje kao djeca.

Najdelikatniji dio upitnika odnosio se na osobnu izloženost nasilju, odnosno osobno iskustvo s nasiljem u kojem su bili žrtvama. Zabrinjavajući je postotak ispitanika koji su na pitanje „U dosadašnjem osobnom iskustvu doživio/doživjela sam određene oblike nasilja" odgovorili da ih je $10 \%$ doživjelo fizičko nasilje, $16 \%$ psihičko nasilje, $3 \%$ ekonomsko nasilje i $4 \%$ seksualno nasilje. lako je riječ o sličnoj incidenciji izloženosti pojedinim vrstama zlostavljanja kao i u općoj populaciji, prema podacima navedenima u uvodnom dijelu brošure da je svako treće dijete doživjelo neki oblik nasilja, ovo je vrlo zabrinjavajući podatak, tim više što je na sljedeće pitanje „Ako ste doživjeli nasilje u svojem osobnom iskustvu, jeste li zatražili pomoć?" samo njih $70 \%$ ponovilo da nije doživjelo nasilje. Time je indirektno potvrđen podatak o $30 \%$ ispitanika koji su doživjeli neki oblik nasilja u obitelji. Vrlo je alarmantan podatak da je od $30 \%$ zlostavljanih ispitanika samo $4 \%$ zatražilo neki oblik pomoći, dok svi ostali, njih $26 \%$, nisu tražili pomoć. Od onih koji su zatražili pomoć gotovo su svi zatražili pomoć policije, što potvrđuje da Romi i dalje najveće povjerenje imaju u policiju. 


\subsection{Stavovi o nasilju u obitelji}

U bloku od 10 pitanja istražili su se stavovi o nasilju u obitelji tako da su ispitanici izrazili svoj stupanja slaganja sa svakom od deset navedenih tvrdnji označivši svoj stupanja slaganja u rasponu od 1 - uopće se ne slažem do 5 - u potpunosti se slažem.

$\mathrm{Na}$ tvrdnju da je nasilje u obitelji privatna stvar i okolina se ne treba previše miješati u to visok postotak ispitanika ispravna je prepoznao da je riječ o mitu i potpuno krivoj tezi, jer ih se $43 \%$ uopće ne slaže, a daljnjih $17 \%$ djelomično ne slaže s time, što ukupno daje $60 \%$ ispitanika koji ispravno odbacuju takvu tvrdnju. Međutim, visok je postotak onih koji nemaju jasno izgrađeno mišljenje o tom problemu - njih $26 \%$ niti se slaže niti se ne slaže i kod tog dijela ispitanika ima prostora i postoji potreba za edukacijski rad.

Tvrdnja da nasilje prestaje napuštanjem zlostavljača potpuno je kriva jer nasilje ne prestaje odlaskom žrtve, već dio zlostavljača slijedi žrtvu i dalje je izlaže nasilju. Toga je svjesno $45 \%$ ispitanika koji su tu tvrdnju u potpunosti ili djelomično odbacili. Kod onih ispitanika koji se s tvrdnjom slažu, njih $37 \%$, potrebno je edukacijskim radom osvijestiti kompleksnost odnosa žrtve i zlostavljača.

Nasilje u obitelji je realnost, ne samo romskih obitelji nego hrvatskog društva. Ohrabrujuće je da je samo $10 \%$ ispitanika krivo odgovorilo na tvrdnju da nasilje u obitelji nije baš toliko prisutno, ali ostaje $30 \%$ ambivalentnih koji o tome nemaju mišljenje. Ispravnim podacima i prikazima slučajeva potrebno je kod mladih osvijestiti veličinu i značaj problema nasilja u obitelji.

Prijetnje fizičkim nasiljem spadaju u oblik psihičkog nasilja zastrašivanjem i, nažalost, u zatvorenom ciklusu obiteljskog nasilja prijetnje u jednom trenutku prerastaju u realizaciju fizičkog obračuna. Nažalost, čak $20 \%$ ispitanika toga nije svjesno, a još ih $16 \%$ nema definirano mišljenje, što ukupno daje više od jedne trećine ispi-

\begin{tabular}{|c|c|c|c|c|c|}
\hline Tvrdnja & \multicolumn{5}{|c|}{ Odnosi u obitelji i nasilje u obitelji privatna su stvar i okolina se ne treba previše miješati u to. } \\
\hline $\begin{array}{l}\text { Stupanj } \\
\text { slaganja }\end{array}$ & $\begin{array}{l}\text { uopće se ne } \\
\text { slažem }\end{array}$ & $\begin{array}{c}\text { djelomično se ne } \\
\text { slažem }\end{array}$ & $\begin{array}{l}\text { niti se slažem niti } \\
\text { se ne slažem }\end{array}$ & $\begin{array}{l}\text { djelomično se } \\
\text { slažem }\end{array}$ & $\begin{array}{l}\text { u potpunosti se } \\
\text { slažem }\end{array}$ \\
\hline Postotak \% & 43 & 17 & 26 & 7 & 6 \\
\hline
\end{tabular}

\begin{tabular}{|c|c|c|c|c|c|}
\hline Tvrdnja & $\mathrm{Dab}$ & ilje prestalo, žrtv & nora samo napu & 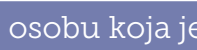 & stavlja. \\
\hline $\begin{array}{l}\text { Stupanj } \\
\text { slaganja }\end{array}$ & $\begin{array}{l}\text { uopće se ne } \\
\text { slažem }\end{array}$ & $\begin{array}{c}\text { djelomično se ne } \\
\text { slažem }\end{array}$ & $\begin{array}{l}\text { niti se slažem niti } \\
\text { se ne slažem }\end{array}$ & $\begin{array}{l}\text { djelomično se } \\
\text { slažem }\end{array}$ & $\begin{array}{l}\text { u potpunosti se } \\
\text { slažem }\end{array}$ \\
\hline Postotak \% & 28 & 17 & 17 & 17 & 20 \\
\hline
\end{tabular}

\begin{tabular}{|c|c|c|c|c|c|}
\hline \multicolumn{6}{|c|}{ „Nasilje u obitelji nije baš toliko prisutno i više se samo priča o tome." } \\
\hline Tvrdnja & \multicolumn{5}{|c|}{ Nasilje u obitelji nije baš toliko prisutno i više se samo priča o tome. } \\
\hline $\begin{array}{l}\text { Stupanj } \\
\text { slaganja }\end{array}$ & $\begin{array}{l}\text { uopće se ne } \\
\text { slažem }\end{array}$ & $\begin{array}{c}\text { djelomično se ne } \\
\text { slažem }\end{array}$ & $\begin{array}{l}\text { niti se slažem niti } \\
\text { se ne slažem }\end{array}$ & $\begin{array}{l}\text { djelomično se } \\
\text { slažem }\end{array}$ & $\begin{array}{c}\text { u potpunosti se } \\
\text { slažem }\end{array}$ \\
\hline Postotak \% & 45 & 14 & 30 & 6 & 4 \\
\hline
\end{tabular}

\begin{tabular}{|c|c|c|c|c|c|}
\hline Tvrdnja & Nije & o zlostavljanju a & osoba samo pri & tjelesnim ozlje & anjem. \\
\hline $\begin{array}{l}\text { Stupanj } \\
\text { slaganja }\end{array}$ & $\begin{array}{l}\text { uopće se ne } \\
\text { slažem }\end{array}$ & $\begin{array}{l}\text { djelomično se ne } \\
\text { slažem }\end{array}$ & $\begin{array}{l}\text { niti se slažem niti } \\
\text { se ne slažem }\end{array}$ & $\begin{array}{l}\text { djelomično se } \\
\text { slažem }\end{array}$ & $\begin{array}{l}\text { u potpunosti se } \\
\text { slažem }\end{array}$ \\
\hline Postotak \% & 49 & 14 & 16 & 10 & 10 \\
\hline
\end{tabular}


tanika koje je potrebno upoznati s ciklusima obiteljskog nasilja i osvijestiti da prijetnje nisu puke riječi, nego grubi oblik nasilja nasilnika nad žrtvom.

Na tvrdnju da obiteljske tučnjave nisu ozbiljne i da se to može dogoditi u svakom braku ispravno reagira čak $79 \%$ ispitanika koji takvu tezu jasno odbacuju. Vrlo mali postotak ispitanika, samo njih $16 \%$, s tom se tvrdnjom slaže, no i to je prevelik postotak.

Visok postotak ispitanika, njih $60 \%$, ispravno smatra da se osoba koja je nasilna može promijeniti i da je važno raditi na tome. No rad $s$ nasilnicima ozbiljan je posao koji traži multidisciplinarni pristup i uključivanje niza stručnjaka u koje zajednica mora imati povjerenje, od socijalne službe do psihološke pomoći, uz druge službe, te je riječ o dugotrajnom i mukotrpnom radu.

Jedan je od klasičnih mitova da se zlostavljanje u obitelji događa samo u siromašnim društvenim slojevima. To uopće nije tako, već se nasilje događa u svim slojevima društva. To ispravno uočava $74 \%$ ispitanika, a kod njih $17 \%$ potrebno je raditi na razlučivanju veze između siromaštva i nasilja.

Vrlo se često žrtvu okrivljava da je svojim postupcima izazvala zlostavljača i dovela do njegove reakcije, što je potpuno krivo postavljanje odnosa u nasilničkim obiteljima i vezama. Žrtva nikad ne snosi ni najmanju krivicu za zlostavljanje kojem bude izložena, već je zlostavljač taj čije se nasilničko ponašanje nikako ne može opravdati. Kod ovog pitanja dobivena je velika disperzija rezultata, pri čemu čak $41 \%$ ispitanika nema mišljenje o tome, dok ih još $29 \%$ odbacuje tvrdnju da zlostavljač uzrokuje nasilje, a ne žrtva svojim postupcima. Tek vrlo mali postotak ispitanika, njih $30 \%$, ispravno zauzima stav da jedini zlostavljač uzrokuje nasilje, bez okrivljavanja žrtve. Kod ovog pitanja dobiven je najveći postotak neodlučnih odgovora, kao i što kod ovog pitanja

\begin{tabular}{|c|c|c|c|c|c|}
\hline \multicolumn{5}{c|}{$\begin{array}{c}\text { Tablica 5. Stupanj prihvaćanja teze } \\
\text { „Obiteljske tučnjave nisu ozbiljne.” }\end{array}$} \\
\hline Tvrdnja & \multicolumn{4}{|c|}{ Obiteljske tučnjave nisu ozbiljne. To se može dogoditi u svakom braku. } \\
\hline $\begin{array}{c}\text { Stupanj } \\
\text { slaganja }\end{array}$ & $\begin{array}{c}\text { uopće se ne } \\
\text { slažem }\end{array}$ & $\begin{array}{c}\text { djelomično se ne } \\
\text { slažem }\end{array}$ & $\begin{array}{c}\text { niti se slažem niti } \\
\text { se ne slažem }\end{array}$ & $\begin{array}{c}\text { djelomično se } \\
\text { slažem }\end{array}$ & $\begin{array}{c}\text { u potpunosti se } \\
\text { slažem }\end{array}$ \\
\hline Postotak \% & 62 & 17 & 4 & 10 & 6
\end{tabular}

\begin{tabular}{|c|c|c|c|c|c|}
\hline \multicolumn{5}{c|}{$\begin{array}{c}\text { Tablica 6. Stupanj prihvaćanja teze } \\
\text { Osoba koja je nasilna može se promijeniti i važno je raditi na tome." }\end{array}$} \\
\hline Tvrdnja & \multicolumn{4}{|c|}{ Osoba koja je nasilna može se promijeniti i važno je raditi na tome. } \\
\hline $\begin{array}{c}\text { Stupanj } \\
\text { slaganja }\end{array}$ & $\begin{array}{c}\text { uopće se ne } \\
\text { slažem }\end{array}$ & $\begin{array}{c}\text { djelomično se ne } \\
\text { slažem }\end{array}$ & $\begin{array}{c}\text { niti se slažem niti } \\
\text { se ne slažem }\end{array}$ & $\begin{array}{c}\text { djelomično se } \\
\text { slažem }\end{array}$ & $\begin{array}{c}\text { u potpunosti se } \\
\text { slažem }\end{array}$ \\
\hline Postotak $\%$ & 7 & 9 & 25 & 22 & 38 \\
\hline
\end{tabular}

\begin{tabular}{|c|c|c|c|c|c|}
\hline \multicolumn{5}{c|}{$\begin{array}{c}\text { Tablica 7. Stupanj prihvaćanja teze } \\
\text { „Zlostavljanje u obitelji događa se samo u siromašnim društvenim slojevima." }\end{array}$} \\
\hline Tvrdnja & \multicolumn{2}{c|}{ Zlostavljanje u obitelji događa se samo u siromašnim društvenim slojevima. } \\
\hline $\begin{array}{c}\text { Stupanj } \\
\text { slaganja }\end{array}$ & $\begin{array}{c}\text { uopće se ne } \\
\text { slažem }\end{array}$ & $\begin{array}{c}\text { djelomično se ne } \\
\text { slažem }\end{array}$ & $\begin{array}{c}\text { niti se slažem niti } \\
\text { se ne slažem }\end{array}$ & $\begin{array}{c}\text { djelomično se } \\
\text { slažem }\end{array}$ & $\begin{array}{c}\text { u potpunosti se } \\
\text { slažem }\end{array}$ \\
\hline Postotak $\%$ & 65 & 9 & 17 & 4 & 4
\end{tabular}

\begin{tabular}{|c|c|c|c|c|c|}
\hline \multicolumn{6}{|c|}{$\begin{array}{l}\text { Tablica 4. Stupanj prihvaćanja teze } \\
\text { „Zlostavljač uzrokuje nasilje, a ne žrtva svojim postupcima." }\end{array}$} \\
\hline Tvrdnja & \multicolumn{5}{|c|}{ Zlostavljač uzrokuje nasilje, a ne žrtva svojim postupcima. } \\
\hline $\begin{array}{l}\text { Stupanj } \\
\text { slaganja }\end{array}$ & $\begin{array}{l}\text { uopće se ne } \\
\text { slažem }\end{array}$ & $\begin{array}{l}\text { djelomično se ne } \\
\text { slažem }\end{array}$ & $\begin{array}{l}\text { niti se slažem niti } \\
\text { se ne slažem }\end{array}$ & $\begin{array}{l}\text { djelomično se } \\
\text { slažem }\end{array}$ & $\begin{array}{l}\text { u potpunosti se } \\
\text { slažem }\end{array}$ \\
\hline Postotak \% & 16 & 13 & 41 & 16 & 14 \\
\hline
\end{tabular}


najmanji postotak ispitanika ima ispravan $\mathrm{i}$ jasan stav. Upravo taj problem odnosa zlostavljača i žrtve ključan je za razumijevanje dinamike obiteljskog nasilja i za osvještavanje razumijevanja uzroka nasilja potrebno je pojačati edukativni rad, posebice s mladima.

Jednako kao i na pitanje o nasilju kao dominantnom problemu u siromašnim obiteljima, i kod ovog pitanja samo $20 \%$ ispitanika pogrešno smatra da nasilje postoji samo u problematičnim obiteljima. Riječ je o mitu koji je potrebno razotkrivati, budući da se nasilje često događa iza zidova naizgled uzornih obitelji, gdje iza fasade godinama bude prikrivano brutalno nasilje nad slabijim članovima obitelji, najčešće ženom i djecom.

U vlastitu zaštićenost od uvlačenja u začarani krug nasilja u obitelji, nažalost, idealistički vjeruje čak $57 \%$ ispitanika. Suprotno njima, čak $29 \%$ svjesno je da i oni mogu postati žrtvama obiteljskog nasilja. Upravo sličan postotak, oko trećine populacije, i jest odgovorio pozitivno na pitanja o vlastitom izloženosti nasilju i osobnom iskustvu $s$ nasilničkim ponašanjem zlostavljača. Mladima treba jasno reći da svatko može postati žrtva nasilja, da se nasilje ne događa nekom drugom i da se samo edukacijom i osnaživanjem mogu stvarati preduvjeti za izlazak iz začaranog kruga perpetuiranja nasilja.

Rezultati ovog istraživanja mogu se usporediti tek s rezultatima manjeg dijela istraživanja koji su objavljeni 2018. godine u dokumentu pod nazivom Uključivanje Roma u hrvatsko društvo: istraživanje baznih podataka, koji donosi podatak da je na pitanje o tome jesu li ikada doživjeli neki oblik nasilja od nekog člana svoje obitelji $12,0 \%$ ispitanika romske manjine odgovorilo potvrdno. Na pitanje o tome jesu li ikada osjetile strah od svojega supruga ili partnera $14,3 \%$ ispitanica odgovorilo je potvrdno. Na pi- tanje o tome jesu li ikada doživjele neke oblik nasilja od bilo kojeg muškarca s kojim su tijekom života bile u intimnoj vezi još je manji udio onih žena koje su odgovorile potvrdno. Da su to doživjele od svojeg sadašnjeg supruga ili partnera navelo je 4,8 \%, žena, dok ih je 6,3\% navelo da su to doživjele od bivšeg supruga odnosno partnera. Da su bile žrtve psihičkog nasilja, bilo jednom bilo više puta, navelo je $36,7 \%$ ispitanica, a $14,5 \%$ in je dobilo prijetnju ili prijetnje da će biti fizički ozlijeđene. Da su doživjele fizičko nasilje od svojih supruga/partnera, i to tako da su bacali stvari na njih, bilo jednom bilo više puta, navelo je $11,5 \%$ žena. Također, $14,1 \%$ žena navelo je da ih je suprug namjerno grubo gurao, vukao za kosu, uši i slično, a $18,5 \%$ navelo je da ih je suprug/ partner ošamario, udario rukom ili nogom ili pak pretukao. Nadalje, 8,7 \% pripadnica romske nacionalne manjine navelo je da su imale seksualni odnos protiv svoje volje sa suprugom/partnerom, bilo jednom bilo više puta. ${ }^{9} \mathrm{U}$ odnosu na ove podatke, rezultati ovog istraživanja još su povoljniji, pri čemu se podaci vjerojatno razlikuju u različitim županijama.

\section{Zaključak}

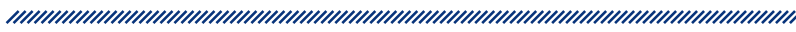

Romi su najugroženija manjinska zajednica u Hrvatskoj, a njihova niska ekonomska moć, nizak stupanj obrazovanja, mali broj zaposlenih, loši uvjeti stanovanja, kao i brojne predrasude uzroci su njihova teškog položaja u društvu. Ovo je istraživanje pokazalo da je problem nasilja u obitelji prisutan i među romskom populacijom. lako je bila riječ o prigodnom uzorku pa nije moguća genera-

\begin{tabular}{|c|c|c|c|c|c|}
\hline \multicolumn{7}{c}{} & \multicolumn{5}{c}{ Tablica 9. Stupanj prihvaćanja teze } \\
„Nasilje postoji samo u problematičnim obiteljima.”
\end{tabular}

\begin{tabular}{|c|c|c|c|c|c|}
\hline Tvrdnja & $\overline{\mathrm{Me}}$ & nikada ne bi mc & o dogoditi da bu & žrtva nasilja & itelji. \\
\hline $\begin{array}{l}\text { Stupanj } \\
\text { slaganja }\end{array}$ & $\begin{array}{l}\text { uopće se ne } \\
\text { slažem }\end{array}$ & $\begin{array}{c}\text { djelomično se ne } \\
\text { slažem }\end{array}$ & $\begin{array}{l}\text { niti se slažem niti } \\
\text { se ne slažem }\end{array}$ & $\begin{array}{l}\text { djelomično se } \\
\text { slažem }\end{array}$ & $\begin{array}{l}\text { u potpunosti se } \\
\text { slažem }\end{array}$ \\
\hline Postotak \% & 19 & 10 & 14 & 12 & 45 \\
\hline
\end{tabular}


lizacija rezultata na ukupnu populaciju, dobiveni rezultati upućuju da je incidencija izloženosti nasilju u među pripadnicima romske populacije u promatranoj županiji oko $30 \%$, pri čemu se najviše ističe izloženost psihičkom i fizičkom nasilju. Time je i dokazana prva hipoteza da nema razlike $u$ incidenciji izloženosti nasilju u obitelji između pripadnika romske nacionalne manjine u odnosu na neromsku populaciju na razini sekundarnih podataka za Republiku Hrvatsku. Postotak ispitanika koji potvrdno odgovaraju a pitanja o izloženosti nasilju u obitelji ne razlikuje se od postotka u općoj populaciji, čime se razbija mit o većem nasilnom ponašanju među Romima u odnosu na neromsku populaciju. Također, iako većinu ispitanika čine mlade osobe, već i kod njih postoji strah od prijavljivanja nasilja i izbjegavanje prijavljivanja doživljenog, kao i nepovjerenje u institucije unutar sustava, posebice u socijalne službe, a pogotovo stručne službe unutar obrazovnog sustava, koje bi po svojoj ulozi i položaju u sustavu mladima trebale biti najbliže. Dokazana je i druga hipoteza prema kojoj žrtve nasilja iznimno rijetko prijavljuju doživljeno nasilje u obitelji i pokazuju nepovjerenje prema institucijama u sustavu. Postotak osoba koje su prijavile nasilje iznimno je malen, a jasno je istaknuto da je policija jedino tijelo u koje žrtve imaju barem nekakvo povjerenje. Većina ispitanika jasno prepoznaje prosjačenje kao oblik zlostavljanja djece i odbacuje osobnu izloženost takvom ponašanju. Prosjačenje se ispravno prepoznaje kao oblik nasilja nad djecom i vrlo visok postotak ispitanika pokazuje jasnu svijest da oni sami mogu prekinuti krug transgeneracijskog prenošenja nasilja i iskazuju jasnu spremnost da svoju djecu nikad ne uključe u takve oblike iskorištavanja.

Potvrđena je i treća hipoteza prema kojoj romska populacija nema jasno izgrađene stavove o odnosima nasilnik - žrtva i dijeli predrasude o krivnji žrtve za doživljeno nasilje. Naime, analiza mitova o obiteljskom nasilju izdvojila je da i dalje vrlo visok postotak ispitanika smatra da je žrtva kriva za doživljeno nasilje jer svojim ponašanjem izaziva nasilnika. Također, gotovo polovica ispitanika nema izgrađeno mišljenje o tom problemu, tako da je potrebno uložiti dodatni napor u organizaciju edukacija za mlade o obiteljskom nasilju kako bi s pomoću jasnih informacija i prikaza slučajeva mladi osvijestili veličinu problema.

Na temelju dobivenih rezultata može se preporučiti da je rad s mladima od presudne važnosti, a edukacija je put kojim će se postupno učinkovito razbiti predrasude i mitovi koji prate romsku populaciju. S druge strane, ispitanicima je poslana jasna poruka da se u slučaju nasilja u obitelji nasilje mora prijaviti, a žrtva mora zatražiti pomoć.

\section{Referencije}

1. Valković M. Solidarnost i pravda kao temelj socijalne države. Revija za socijalnu politiku; 1996, (3)3-4, 217-238.

2. Ajduković M. Nasilje nad ženom u Hrvatskoj. U: Ajduković M, Pavleković G. (ur.) Nasilje nad ženom u obitelji. Zagreb: Društvo za psihološku pomoć; 2003. str. 53-67.

3. Watts C, Mayhew S. Reproductive Health Services and Intimate Partner Violence: Shaping a Pragmatic Response in Sub-Saharan Africa. International Family Planning Perspectives, 2004; 30, 207-213.

4. Appelt B, Kaselitz V. More than a roof over your head. Beč: European Information Center Against Violence Against Women; 2002.

5. Johnson H, Ollus N, Nevala S. Violence against women. New York: Springer; 2008.

6. Godeč Ž. Veliko Nacionalovo istraživanje o položaju žene u Hrvatskoj, Nacional: Zagreb, 12.7.2000.

7. Ajduković D, Ajduković M. Nasilje u obitelji: što zdravstveni djelatnici mogu učiniti. Medicina Fluminensis, 2010, 46(3), 292-299.

8. Vlada RH. Nacionalna strategiju uključivanja Roma za razdoblje od 2013. do 2020. Zagreb: Vlada RH; 2013.

9. Kunac S, Klasnić K, Lalić S. Inclusion of Roma in Croatian Society: Research of Basic Data. Zagreb; 2018. 


\section{ATTITUDES OF THE ROMA POPULATION IN THE BJELOVAR-BILOGORA COUNTY ON DOMESTIC VIOLENCE}

\author{
1 Aleksandar Racz \\ 2 Veljko Kajtazi \\ 1 University of Applied Health Sciences Zagreb \\ 2 Association of Roma in the Republic of Croatia "Kali Sara"
}

\section{Summary}

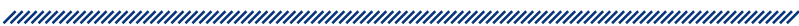

The overall goal of the Croatian National Roma Inclusion Strategy is to improve the position of the Roma national minority in the Republic of Croatia by reducing the multidimensional socio-economic gap between the Roma and the rest of the population and to achieve, in a harmonized, open and transparent way, full inclusion of Roma in all segments of the society and community. The main aim of the research was to investigate the views of the members of the Roma population from Bjelovar-Bilogora County on domestic violence and to investigate the type and extent of their exposure to certain forms of violence. The auxiliary goal was to investigate the beliefs and attitudes of respondents about child begging, and the beliefs and attitudes of respondents about their trust in the institutions as a place of reporting violence and providing the victims with protection in cases of domestic violence. The research was conducted on a convenient sample of 70 participants of workshops on the topic of adopting social skills aimed at reducing the unacceptable behavior of children and young people organized by the Association of Roma Kali Sara in Grubišno Polje and Bjelovar in January 2019. The data were processed by standard SPSS software package. The results confirmed all three hypotheses of the research: there is no difference in the incidence of domestic violence among members of the Roma minority in relation to the secondary data on domestic violence in the non-Roma population in the Republic of Croatia; the victims of violence rarely report violence experienced in the family and show mistrust towards institutions in the system, and that the Roma population has no clear attitudes towards the victimaggressor relationship and shares prejudices about the victim's fault for experiencing violence.

Keywords: family violence, Roma, integration, Kali Sara 